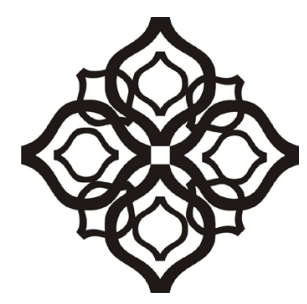

Shirkah

Journal of Economics and Business 


\section{Shirkah}

Journal of Economics and Business

Vol. 4, No. 2, May-August 2019

ISSN: 2503-4235 (p); 2503-4243 (e)

\section{Editor in Chief}

Fitri Wulandari

\section{Managing Editor}

Jasanta Peranginangin

\section{Editorial Boards}

AAbdul Azim Islahi,

Islamic Economics Institute, King Abdulaziz University, Saudi Arabia

Abu Umar Faruq Ahmad,

UBD School of Business and Economics Universiti, Brunei Darussalam

Cedomir Nestorovic,

ESSEC Business School Asia Pacific, Singapore

Johan Fischer,

Department of Social Sciences and Business Roskilde Universitetscenter, Denmark Muhamed Zulkhibri,

Islamic Research and Training Institute, Islamic Development Bank, Saudi Arabia M. Kabir Hassan,

Department of Economics and Finance, University of New Orleans, United States Musa Asy'arie,

Faculty of Islamic Economics and Business, IAIN Surakarta, Indonesia

Nunung Nurul Hidayah,

Aston Business School, Aston University, Birmingham, United Kingdom

Saim Kayadibi,

Department of Economics, Kulliyyah of Economics and Management Science,

International Islamic University Malaysia, Malaysia

Shaikh M Ghazanfar,

Departement of Economics, University of Idaho, Russian Federation 
Sigit S. Wibowo,

Department of Management, Faculty of Economics and Business, Universitas Indonesia, Indonesia

Vihang R. Errunza,

Desmarais Global Finance Research Centre, Desautels Faculty and Management, McGill University, Canada

\section{Assistant to Editor}

M. Endy Saputro

M. Zainal Anwar

Shirkah Journal of Economics and Business is a peer-reviewed journal published three times a year (January-April, May-August and September-December) by Faculty of Islamic Economics and Business, Institut Agama Islam Negeri (IAIN) Surakarta Central Java, Indonesia. The main objective of Shirkah is to offer an academic space of exchange ideas and initiate the increase number of qualified article produced by postgraduate students, practitioners and academicians.

\section{Editorial Office}

Ruang Jurnal Shirkah

Lantai Dasar, Sayap Barat, Fakultas Ekonomi dan Bisnis Islam, IAIN Surakarta

Jln. Pandawa No. 1, Kartasura, Sukoharjo, Jawa Tengah Kode Pos. 57168

Phone (+62271) 781516 Fax: (+62271)782336

E-mail: shirkahjournal@iainsurakarta.ac.id; shirkahiainsurakarta@gmail.com Website: http://shirkah.or.id/ 


\section{Shirkah}

Journal of Economics and Business

Vol. 4, No. 2, May-August 2019

ISSN: 2503-4235 (p); 2503-4243 (e)

\section{Table of Contents}

\section{Articles}

Abd Hannan

Santripreneurship and Local Wisdom Economic Creative of Pesantren Miftahul Ulum

Muh. Salahuddin

Nurhilaliati

Zaenal Arifin

Entrepreneurship and Economics of Pesantrens in Lombok Island

Abdul Jalil

Alumni Networks and Economic Reinforcement in Pesantren

Ummussabri

Jehan Maya Zayanie

Ahsana Fitria

Rosidatul Kamariah

Bank Wakaf Mikro and Creative Economics in Pesantren Buntet

Farihatul Qamariyah

Muslim Business Women in Indonesia

Fachrurazi

Dwi Srya Atmaja

Zaenuddin Hudi Prasojo

Muslim Businessmen and Chinese Economics in Singkawang 


\title{
Entrepreneurship and Economics of Pesantrens in Lombok Island
}

\author{
Muh. Salahuddin \\ Universitas Islam Negeri (UIN) Mataram \\ salabuddin76@uinmataram.ac.id \\ Nurhilaliati \\ Universitas Islam Negeri (UIN) Mataram \\ nurhilaliati@uinmataram.ac.id \\ Zaenal Arifin \\ Universitas Islam Negeri (UIN) Mataram \\ zaenal.arifin@uinmataram.ac.id
}

\begin{abstract}
Religion is often alleged for being a barrier to development. Pesantren, as one of the instruments of religious empowerment, has occasionally even become subjects juxtaposed with religious failures. In contrast, pesantren has never been modest and consistently responded to every detail of changes. This is where the innovative and creative behavior of pesantren communities is examined. This study aims to analyze such pesantrens in Lombok island improve innovation and creativity to enter the economic and business domain. This study enriches the discourse of economic communities in the pesantren for which some have been structured and others are still looking for ideal patterns for the economic changes that occur in society.
\end{abstract}

Keywords: social change, paradigm, pesantren, entrepreneurship

\section{Introduction}

Religion, particularly Islam, is often confronted with progress and anti-change. Consequently, the identity of poverty, backwardness, ignorance, acts of violence and other negativities are often associated to Islam and its followers. Even worse, Islamic educational institutions (pesantrens) 
are often accused of preserving the above identity, which consequently comes to the conclusion that religion and its instruments are obstacles to economic progress and development (Wahid, Harris, Norton, 2005). Moreover, Islam and the flourishing acts of terrorism in the past few decades are forcibly connected (Irawan and Aziz, 2007). Pesantrens for many people are considered not to make a significant contribution to the development process. Meanwhile, religion along with its devices is often accused of being a barrier to development. In contrast, several studies show that religion is a source of inspiration and value for economic renaissance (Yulianti, 2018; Gidden, 1985; Bellah, 1984).

Historically, the presence of pesantren was being a response to the reality that grew during its age. Madjid (1997) notice that pesantren was an institution created by Hindu-Buddhists, and Muslims continued and being islamized it. Aguk (2018) describes the genealogy of pesantren from the kingdom era until the rise of pesantren in Java. This fact implies that pesantren was originally established and developed by the native Indonesians. As an old religious institution, pesantren has power to defend, adapt, and develop within a society (Asrohah, 2011). The aforementioned power entails, first, pesantren is owned, managed, and developed by community. Typically, these Islamic boarding schools are jointly established by kyailtuan guru (religious leaders) and their followers (Dhofier, 1997). Sources of developmental funds may come from waqf assets, infaq, zakat, and sadaqah given by kyai and the followers. Second, with the available resources, schools adapt to a variety of ages and every detail of the existing changes. Third, pesantren has strong tradition of adaptation to all kinds of changes in society.

The three aspects above are underpinned with pesantren's academic tradition by prioritizing qawaid al-fiqhiyyah which is anti-statusquo to preserve tradition and adapt to changes. Community of pesantren 
stress to keep the good old traditions and take something better (almuhafazat 'ala al-qadim al-salih wa al-akhz bi al-jadid al-aslah). Pesantren continuously responds to the social change of the reality. As part of the system, obviously the element within pesantren takes a part in dialogue and interaction with other sub-systems (Asmani, 2016). Indicators of the interaction of pesantren with the system and the supra system that appear in the changes of the design of internal-external management of pesantren. This is also an anti-thesis to the statement that pesantrens are educational institutions categorized into second class category, which only deliberate religion (Bruinessen, 1992). The dialogical interaction of pesantren with its internal and external system brings about reformation, which in system theory is called emergent properties (Mu'adz, 2014).

The pesantren's reformation lies in the development of the pesantren model. Asrohah (2011) classifies four models of pesantren development, namely first, salaf pesantren generally admitted as the original model institution of the pesantren. The orientation of studying in pesantren salaf is to master religious knowledge driven from classic Arabic book (kitab kuning). The students in this pesantren are prepared to be the candidates for scholars. Second, pesantren with formal education, which have their own curriculum and do not follow governmentrelated curriculum. Third, pesantren with community development mission and integrated program from elementary school up to academy level. Apart from religious knowledge, the study is focused on skill for development programs. Fourth, dormitory model; the pesantren provides a dormitory for students to stay or students may optionally study outside of pesantren. Transfer of religious knowledge is conducted out of school hours. Based on the above criteria, Wahid (2011) explains that schools are developed by social change in the community, and it was a part of the instruments of social transformation in Indonesia. 
One form of the social transformation is the intention and attention of pesantren's stakeholders in the economic field. In some modern pesantrens, they have long acclaimed that they are educational institutions producing self-sufficient/ independent santri. Therefore, pesantrens provide equipment of knowledge and skills capable to direct santri to independent lives. Despite limited space, pesantrens are always connected to external reality substantively, intellectually, spiritually, morally, socially, and emotionally.

\section{Foundations of Entrepreneurship}

Entrepreneurship has been developed on the basis of saturation in fulfilling the needs of human life. Innovation and creativity are needed to meet the unlimited needs of human life. Innovation and creativity cover all areas of human life. Entrepreneurship is not only associated with unstitch economic activities, but also related to the whole life system which includes social, education, religion, technology, and others. All of them will have an impact on strengthening the economy of the community. In the world of education, it is known as the link and match that demands the content of the educational process linked to the reality of the needs of the workplace. In a government system, it is required to be effective and efficient, which then presents the concept of governmental entrepreneurship. ESQ is a form of innovation and creativity in strengthening performance with understanding religion. Implementing the concept of women's economic empowerment in Bangladesh, Yunus formulate a grand design of social entrepreneurship (Yunus and Weber, 2007). Substantively, entrepreneurial activity in non-economic institutions is not directly related to economic activity, but the economic impact that is generated is real and felt. Therefore, the economy must be seen in a system that interacts with other systems in society. 
Of the many conceptual descriptions of entrepreneurship, there are at least several core points that can be taken. First, entrepreneurship is a value manifested in behavior that is used as a resource, a driving force, goals, tactics, tips, processes, and business outcomes (Suyanto, 2004). In another definition, entrepreneurship is the ability to combine all sources to achieve maximum results. In this case managerial competence is the basic that must be met by an entrepreneur. With that managerial capability an entrepreneur can develop / maintain the 'wings' of the business creatively. Second, entrepreneurship is a framework of values (science, religion, ethics) needed to start a business (Shane, 2003). This value is used as a motivation to spawn creative and innovative ideas. Creativity and innovation are the spirit of entrepreneurship. The value framework behind the entrepreneurial activities will greatly influence the concept, work, and purpose of business activities. Entrepreneurship based on capitalism will give birth to an oppressive economic class. Entrepreneurship departing from the ethics of religion (Islam) will have activity and business results oriented to the guidance of Islamic values (Khoirusalim, 2007). Entrepreneurship will be greatly influenced by activities, concepts, and objectives by a framework of values surrounding it within business reality.

Third, entrepreneurship is about capturing and creating opportunities. The ability to capture and create this opportunity is related to the keenness of oness intuition in seeing, evaluating, interpreting, and predicting reality. Capturing and creating this opportunity is essentially related to creativity, but is more contextual in nature. This opportunity will also be read/ captured by a leader/ manager who has a far-reaching vision. Therefore, managerial aspects and creativity are a complete force to see holistic-comprehensive opportunities in developing the wings and strength of business. Overton wrote that an entrepreneur is a person who always cultivates his mind to create creativity and innovate for himselfand his 
community. The person is not only thinking, but also realizing the mind in real action (Everton, 2002). It is through entrepreneurship that the essence of the economy of society will run. The touch of entrepreneurship in business activity is a vital spirit that smoothens business domain. This is what Schumpeter called an entrepreneur whose indicators are the use of production techniques, the discovery of basic materials, the expansion of the marketing area of management use, and the use of marketing techniques (Schumpeter, 2003).

To be an entrepreneur there are several myths that often haunt people (Frederick, 2006), namely first, the entrepreneur are doers, not thinkers; second, entrepreneurs are born, not made; third, entrepreneurs are always investors; fourth, entrepreneurs are academic and social misfit; fifth, entrepreneurs must fit the profit, sixth, entrepreneurs have success but experience high failure rates; seventh, entrepreneurs are extreme risk-taker. From this point the question arises whether to become an entrepreneur is nature or nurture. Weert (2010) ensures that entrepreneurs do not emerge from nature's talent, but through a continuous educational process. Therefore, entrepreneurship is something that can be learned, skills that can be taught through formal and non-formal classrooms, and can be transmitted to all groups. Alvarez suggests strategies to create entrepreneurship mindset through cognition, entrepreneurial integrity, and market opportunities (Alvarez \& Busenitz, 2007).

In the world of education, awareness of rapid change in the global era also demands the critical attitude of educational institutions in responding to any changes. UNESCO offers educational paradigm of the key concepts, namely learning to know, learning to do, learning to live together, learning to be, learning throughout life, and learning how to learn. With the education paradigm above, students are expected to actively seek knowledge, practice it in society, learn life, and continue to 
process to seek knowledge. The expected output of the learning process as above is the realization of a critical, innovative and creative attitude which includes aspects of knowledge: psychomotor, and affective. More technically, Cromley (2000) offers transfer of knowledge process by supplying science with a critical attitude and providing a platform for students to gain an adequate learning experience. To form a critical, creative, innovative attitude and gain the learning experience as meant by Cromley, it is necessary to have media that enable it to occur in a sustainable manner. The instruments of science will only be able to be used creatively if they have been practiced, which lead participants to learn to enter the world of creativity (Danaci, 2015). In the context of Islamic education, pesantrens are media that might be used to shape the character of students to become entrepreneurs.

In pesantren tradition, intellectual traditions are established based on Islamic ethics which entail the following, the kyai-santri relationship which is dominated by emotional factors; studying (whatever) is part of humanitarian tasks, and embodying of knowledge is through memorization (Subhan, 2016). The intellectual tradition of pesantren is criticized by some for several reasons; 1) a cult to kyai's personal, 2) studies that only focus on the field of religious studies and leave the reality of social development, 3) it seems chaotic without firm and strong educational goals. However, if back to Freire's concept, pesantren education is a liberating education tied to religious ethic. Pesantren with a togetherness concept can maximize the individuals within them to form communities as a strong market base. At this level, even though pesantren have that potential, wait and see is a change in the ideal paradigm of pesantren management. The paradigm shift is the axis of the development of the pesantren world; from followers to creators, from viewers to players, and from consumers to producers. However, managing pesantren requires 
operational costs that require their leaders and administrators to be critical, creative, and innovative. This attitude is needed as a basis for the development of the pesantren entrepreneurship world.

There are principles taught in pesantren: principle of wish, freedom of act, strong personal management, strong togetherness/ brotherhood, high respect to parent and teachers, science lover, self-contained and simple (Jamaludin, 2012). In several pesantrens affiliated with Pesantren Gontor Ponorogo, the principle above is packaged in the Panca Jiwa Pondok. Not only the slogan, Panca Jiwa Pondok is a doctrine that is taught to every santri as a capital to live in society (Muchsin, 2019). The mental attitude taught to santri is charity, which is based on independence of freedom of act and sincerity, as well as in the context of togetherness. This also shows that pesantrens do not merely prepare santri to become ulama, but also free santri to choose other professions. Therefore, from a long time ago the pesantren provided a 'school of life' for people who were not just 'scholar graduating institutions'.

Pesantrens are miniatures of life, in which hundreds or thousands of people live with different traditions, ethnicities, natures and tendencies. With the reality as above, pesantren community has a definite 'market', and it takes a little courage to cultivate the above potential as a 'turning point of the Indonesian Muslim economy'. In the case of pesantren economic development, Zarkasi (2005) underlined entrepreneurship attitude as follows: well administration, good mentality, work ethics, the panca jiwa pondok, independence in togetherness. Apart from these, the pesantren community must develop congregation for the economy and the economy in congregation (Salahuddin, 2006). In the study of entrepreneurship, the substance is that almost all schools have thought and worked in the realm of social entrepreneurship. Initiators of boarding schools often depart from the logic of how to get something from nothing 
(Leadbeater, 1997). Kyai (the leader of pesantren) is a person who actively think and work, find a way to maintain and develop the boarding school he leads. This attitude of strong will inherent to kyai is the true entrepreneur (Mathias, 2014). Isbah (2016) wrote that kyai takes multi roles in community development, education, social, political, economy, culture, and art.

\section{Mapping Entrepreneurships}

The total number of pesantrens in NTB is 337 distributed in Sumbawa and Lombok Island. The majority of pesantrens are in the island of Lombok. The pattern of management and development of Pesantrens in Lombok is based on theological settings, schools, caregiver's educational and social organizational background. All aspects above influence the values, attitudes, and patterns of the development of the pesantren community. As is typically the case of pesantren tradition, the principals are still the main inspiration and motivator in strengthening pesantren communities (Sunarto, 2019).

Some pesantren leaders think out of the box in developing institutions, apart from the usual pesantrens (Irwan, 2019). In the economic logic it is known as high risk high return, taken by some principals of Pesantren. Pondok Pesantren Nurul Hakim Kediri, Nurul Haramain Narmada, Munirul Arifin Praya, Al-Falah Mataram are a few pesantrens that develop entrepreneurial paradigms in the management of pesantrens. However, many pesantren principals do not know if they use the entrepreneurship paradigm (Djuwaini, 2019). What is in the mind of the principals is simply to maintain and develop pesantrens, prepare students to be ready to live in the community, provide students with the knowledge and skills needed, and fulfill the operational needs of non-material materials for the implementation of education (Arifin, 2019; Djuwaini, 2019; Arafat, 
2019). This is the seed of entrepreneurship education in pesantrens built from two extreme points; awareness of the need to exist and the desire to participate in the developmental processes that exist in society (Djuwaini, 2019). Tan and Siew (2014) wrote that someone who has entrepreneurial spirit is one who has prosperity toward risk taking, internal locus of control, innovative thinking, leadership qualities, strong determination and achievable orientation. The heads of pesantrens in Lombok have begun to think 'out of the box', out of their comfort zone in managing boarding schools. Not merely religion, but integrating, communicating, and interconnecting the world of pesantren with the outside world. Abdullah (2010) wrote that a scholar must analyze his field by integrating other disciplines and recognizing their interconnectivity. Pesantrens are not only for boarding schools, but also as a center of excellence that prepares resources for sustainable human development (Haidari, 2004).

Entrepreneurship practices as described above take different patterns in each pesantren. Entrepreneurship practices are initiated from the awareness of the leadership of pesantren to prepare a better generation who are prepared to develop the community with the provision of knowledge provided during the study in pesantren. The mindset developed in boarding schools with an entrepreneurship paradigm is the producer mindset. The essence of the pesantren environment is a miniature of life in which a variety of resources are available and several sources of production can be developed to strengthen the character of santri. Santri, alumni, congregations, and the general public are markets that can be conditioned to strengthen the pesantren economy. Strengthening critical, innovative and creative education is needed to hone business intuition under parenting based on religious values and ethics; boarding school ethics. This role began to be developed by the pesantren community in Lombok. 


\section{Darul Falah Mataram}

Basically, the pesantren of Darul Falah, Mataram is a halaqah tarekat (sufistic recitation) which routinely holds recitation and remembrance activities together. This halaqah tarekat activity began in 1951 at the TGH Abhar's house. Abhar initiated the establishment of the pesantren. Only in 1993 the manager of Darul Falah initiated the establishment of formal education institutions. Formal education institutions in Darul Falah Mataram involve junior high school, senior high school and academic/ high school level.

The development of the physical building of the Darul Falah boarding school originates from the religious reciters who are performed in a private manner; weekly, monthly, quarter yearly, and annually. The average per-year fund set since 2016-2019 reached 400 up to 500 million rupiahs. From the funds collected emerge creative ideas gradually incarnated in economics and business institutions. Some of the institutions owned by Darul Falah are Pesantrens Cooperatives, hajj travel bureau, umrah travel, waqf groups, workshops, and mineral water production (Lutf, 2019). The entire business unit in the pesantren has only begun in the last 4 years. The opening of the pesantren business unit is carried out in stages, in accordance with the availability of resources that are ready to manage the business unit (Mufti, 2019).

Muammar Arafat, head of the pesantren of Darul Falah is a figure known as the tarekat leader, which is often synonymous with avoiding world affairs. At another point, he thought that the assets owned by Darul Falah should be directed at strengthening and developing the community. In particular, the students, alumni, and congregations in the inside of pesantren. They must have capital, at least knowledge about the business that is obtained from experience in the pesantren. Therefore, every santri in this pesantren is directed to have experience in managing the business units in the pesantren (Lutfi, 2019). 
Formally there is no doctrine of entrepreneurship in the Darul Falah in Mataram. Awareness about entrepreneurship is built through public and routine recitation every dawn delivered by the head of the pesantren. The concept presented is about kasb and charity is related to sustenance. Every work, no matter how small it is will be judged by God and humans. Then work must be oriented to goodness and improvement in the quality of life (Arafat, 2019). This pesantren only provides facilities and media that enable entrepreneurial activity in the pesantren. Pesantrens are miniatures of life, which if used creatively and innovatively will have a strong impact on strengthening generation and development. Our santris wear sarong, but we are not big fish in a little sea is a lyric often recited in front of santri (Mufti, 2019). Darul Falah produce cadres who are confident, stand on their own feet and are not dependent (Arafat, 2019). As long as the basic community needs are not fulfilled, it is our duty to fulfill it, because we cannot speak about hereafter (nobility of values) if we have not fulfilled those basic needs (Arafat, 2019).

In the business unit development activities in the Darul Falah Mataram, what are prioritized are ethical values coupled with the awareness of pesantren as part of a community that has the responsibility to participate in every detail of community change: social, economy, politics, education and others. From the explanation above, there are some interesting prepositions to underline as follows. First, the concept and practice of the tarekat which has been synonymous with zuhud who considered the world as a hindrance to servants toward God has begun to shift in terms of meaning to some of the congregations of the pesantren of Darul Falah Mataram. The shift is based on the concept stating that the world is an afterlife field. Therefore, it is not good for a Muslim to ignore the life of the world, just for the sake of the Hereafter. 
Secondly, due to the shift above, the life of pesantren began to be directed at participatory activities in supporting national; physical, social, mental, and economic development goals. Third, the function of the pesantren which was only limited to socio-religious began to move towards the agent of development in its substantive meaning. Fourth, the source of funding for the development and development of Pesantrens comes from infaq, sadaqah, and waqf from the congregations. The meaning of managing the pesantren's input of funding sources also undergoes a substantive shift. Infaq, sadaqah, and waqf, which have been considered as passive assets, have been shifted to productive assets.

\section{YANMU Praya}

YANMU Praya from its first establishment was initiated by the Tuan Guru who has traveled a lot in the business world. Individually, the basic instinct of TGH Zaenal Arifin, the head of the YANMU pesantren, is in the business world. The initial funding for the construction of this YANMU Pesantren Praya was obtained from the benefits set aside specifically to build pesantren. The construction of Pesantrens is intended to prepare cadres who have strong religious knowledge, good social skills, and skills (skills) needed by the community (Arifin, 2019).

In contrast to the process of establishing pesantren in general, which began with regular recitation in the teacher's house, YANMU Praya started a boarding school with classical models from the junior level with a dormitory system. Since its beginning, YANMU Praya Santri is required to have a competitive advantage and differentiation from other santris of boarding schools. For this reason, at the beginning of its establishment, YANMU Praya sent students to Pare Kediri in a private manner to learn English, which in the next stage brought teachers from Pare to teach English at YANMU, and was assisted by Pare alumni students in 
developing English. Within three years YANMU Praya has become English Community (English village) where almost all the elements in the pesantren can speak English. This is the first step in TGH Zaenal Arifin's entrepreneurship in the field of education.

The tradition of entrepreneurship is also followed in other subjects. In the business world, santris and teaching staff at YANMU Praya are involved in several business units belonging to the Tuan Guru. Some of the business units owned by Tuan Guru are in agriculture, hajj and umrah travel, swallow business, and contractor services. The involvement of santris and teaching staffs in the Tuan Guru's business unit is from the process of production planning, resource distribution, up to marketing management.

In agricultural business units, for example, plans for production of plant species are carried out based on analysis of market and pesantren needs. Variants of seeds, fertilizers, management patterns, and the budget needed in the production process are also determined by the santris and teaching staffs with the approval of Tuan Guru. Agricultural products are also distributed by them who are given the responsibility of managing Tuan Guru's agricultural business unit. At first, many failures were obtained. But for Tuan Guru, that is the learning process (Arifin, 2019). The KBIH and travel business units were also handed over to the teaching staffs in the pesantren. This is intended to expand (market share), and at the same time to train them to communicate widely with the community. The management of KBIH and travel has gone bankrupt, because one of the people who was trusted to manage the business finance was 'running away' by carrying cash from the travel business unit.

Every time a new business opportunity is offered, and there is a need for YANMU Praya to distribute the product, the opportunity is taken by the head of the pesantren. In some cases, for example, when 
entering organic fertilizer products in the NTB region, YANMU Praya immediately offered himself as an NTB distributor (Mansub, 2019). The decision to become a distributor is by testing the intended solution in the land itself. Those involved in the distribution and sale of these products are santris and teaching staffs. Likewise, when offered herbal cigarette products from Yogyakarta, the YANMU Praya team took on the role of the main distributor by involving students, teaching staffs, and alumni in the marketing process. Even for cigarette, YANMU produces its own cigarettes, whose distribution is still limited (Arifin, 2019). Apart from the debate over the halal-illegitimate status of cigarettes, there is certainly an effort made to revive business activities and instill aspects of creativity and innovation for the santris.

For swallow nest business and contractor services, there are not many involving santris and teaching staffs. But some of them are often invited to observe the Tuan Guru's business process closely to only be given knowledge, but not to directly get involved in management. For the internal entrepreneurship in boarding schools, business units like canteens are under the management of the Tuan Guru's wife. Substantially, this business unit exists simply to meet the daily needs of santris. From the beginning, since the santris were between 100 to 1600 people today, the canteen is still like it used to be (Ramadhani, 2019). However, in this canteen, santris can learn to do business on a small scale. Santri is also allowed to carry goods for sale, what is sold is not the same as the one in the canteen. For the development of business ideas, pesantren leaders often discuss with academic teams from economic faculties, financial institutions, and entrepreneurs in Lombok. This means that the Tuan Guru to this day is still thinking about the design of how to develop pesantren entrepreneurship and economic independence, both from the theoreticalacademic and practical sides. 
There are some important notes about the entrepreneurship at YANMU Praya. The head of the pesantren has a strong vision and instinct in business activities, and even pesantrens are also started with business profits set aside. The Tuan Guru's business vision has been imparted to santris and teaching staffs through involvement in a business unit pioneered by the Tuan Gurus. The business units in the pesantren are private property and on behalf of Tuan Guru, not in the name of the boarding school institution. Nevertheless, Tuan Guru's personal assets are used as a medium of entrepreneurship for santris. There has been no specific institutional effort to form a business unit. Tuan Guru with a vision far ahead cannot be well balanced by the existing santris and teaching staffs. The vision of entrepreneurship Tuan Guru has not been able to be translated well in the pesantren community. The vision of Tuan Guru entrepreneurship has not been designed in the pesantren education curriculum, formally or non-formally. Business activities in pesantrens are sometimes incidental, in accordance with the ability of pesantren communities to manage and develop businesses. When a person is not supported, the business is abandoned. The trial and error model is often used to provide a technical experience for pesantren communities.

\section{Nurul Haramain Narmada}

In the 1960s, Nurul Haramain boarding schools were limited to madrasahs (formal schools). Only in 1991, Nurul Haramain became a boarding school with a boarding system. The affiliate education system developed by Nurul Haramain is an educational model adapted from Darussalaam Pesantren in Gontor. Head of pesantren, TGH. Hasanain Djuwaini, is a Gontor alumnus who later completed higher education in Egypt. With the knowledge and experience of education, Djuwaini developed pesantren inherited from his parents. The head of Nurul 
Haramain, is known by santris and teaching staffs as someone who often thinks zigzag in solving problems faced by pesantren. Therefore, it is not surprising that there are many achievements of TGH. Hasanain. Some of them are recipients of the 2011 Ramon Magsaysay Award (Nobel Version of Asia), the 2015 Change of Republika Figures, and the 2017 National Social Entrepreneurs. In this context, Tuan Guru must be qudwah (role model) for the younger generation for a better future life (Djuwaini, 2019).

The urge to be independent in the management of pesantren must begin with sincere intentions to strengthen and develop the quality of humanity. Therefore, Nurul Haramain was developed on the basis of faith, Islam, ihsan, rationality, sharing ideas and experiences, culture and traditions of society, and learning from nature (Djuwaini, 2019). From the basis then its vision was established the realization of holistic and quality male and female students who are useful for the people, with mission realizing male and female students who love and likes committing kindness and truth, loving beauty, being beneficial for the people, affluent and prosper. From the vision and mission of the pesantren Haramain it is illuminated that the santris are prepared to comprehensively and holistically understand about life, with which santri can benefit the community. Santri is expected to be able to color people's lives in the context of partiality to the truth, to maintain sustainability, goodness, and prosper/ social welfare.

Types and business variants of pesantren business units are as follows. eNHa Mart is a pesantren business unit that serves Santri in terms of daily needs. From this business unit, the average net profit that can be achieved is around Rp. 10,000,000 - up to Rp. 13,000,000 / month. This business is under the responsibility of a teacher. The management involves a team of teachers and some santris. The santri canteen is a business unit of pesantrens that specifically meets the needs of santri snacks. Snacks in the canteen are from the hands of the teachers in the pesantren. This 
canteen business is controlled by a teacher who is assisted by several junior teachers and santri teams. From this canteen business, the average profit is Rp. 4,000,000/ month. The santri restaurant is a business unit of pesantrens that serve additional food for santri. This business is also managed by teachers involving students, who on average produce net income of Rp. 3,000,000/ month.

Haramain Distribution Center (HDC) is a business unit that supplies goods for all business units in the pesantren. Not only the needs of boarding schools, HDC serves the needs of society in general. The alumni of Nurul Haramain who opened the business also took goods from this HDC. This business unit can bring a net profit of Rp. 7,000,000/ month. Haramain Nursery and Waste Management is a social business unit for environmental conservation. This business unit serves proposals for public activities related to environmental preservation. Occasionally, if there is an auction of a nursery project from the government that provides a budget, then this business unit sells seeds according to market prices. This nursery business is carried out continuously in accordance with the pesantren's vision that aims to prosper the community. Nurseries are conducted regularly and routinely. The seeds that are prepared are plants that live in the forest. While the waste processing unit is a Nurul Haramain creative team in empowering garbage in the community.

Madani Computer and Photo is an operational business unit that is located outside the pesantren which is managed by a team of IT teachers by involving several santris. Aside from being a business unit, this business is also used as an IT learning media for santris. Madani Super Champ (English and Tahfiz Course) is a specific educational institution that manages English language skills and memorization of Quran by the santris and general public. A special place on the outskirts of the forest is the creative result of forest conservation by Nurul's team and the community. There were many 
participants from outside of Lombok with a three-month dormitory education package model. This is Nurul Haramain's edupreneurship. From this business unit, the average monthly income can be obtained by Rp. 7,000,000 - to $11,000,000$. Haramain Water is a refill water business unit which today is still focused on serving the drinking water needs of Santri, whose average income is around Rp. 5,000,000

Haramain Mini Bank is a saving and loan financial service unit that only serves pesantren communities. Aside from being a business unit, this institution is also an educational institution for students who study economics and accounting. Haramain Laundry is a business unit that only serves santri laundry, with average income of Rp. 3,000,000, - during the active period of santri. Bahrain Cilok and Baksoare pesantren-owned business units that supply goods obtained from Nurul Haramain alumni. The model is to deposit goods with a price difference. This type of business is to bind the emotions of the alumni with the pesantren. Haramain Pro AB Chicken is a business unit managed by teachers and santris. However, after the earthquake in Lombok, this business unit went bankrupt because of the lack of buyers. Narmada, the location of Nurul Haramain was the area categorized as severely damaged area by the earthquake.

Haramain Trans is a transportation business unit along with NTB promotion as the world's halal tourism center. Nurul Haramain responded to this by opening a travel unit. As of today, Nurul Haramain has 3 bus fleets and other small vehicles for travel operations. From this travel, the average income is above Rp. 10,000,000/ month. Haramain Photocopy is a business unit outside the boarding school whose average income reaches Rp.2,000,000/ month. Haramain Mushroom is a business unit of mushroom cultivation to supply local market demand. The business has not been maximally developed, but still runs with an average income of over Rp.1,000,000/ month. 
Haramain Lele and Perikanan are fish production units to fulfill regional domestic markets, with an average income of Rp. 3,000,000/ month. Haramain Mart is a business unit outside the pesantren whose design will be developed as Alfamart equivalent. In the future, it is expected that the general public will participate in developing this business in the form of share ownership in this business. This business has only been running for 1 year, with an average income of Rp.2,000,000/ month. Haramain food and Bakery is a professional business unit developed to meet the needs of modern society. Even though it has only been opened for 4 months, the public response to this business unit is quite good. And in the future, it will be developed into a typical Lombok souvenir manufacturer. This business involves many santris and teachers in its management.

Haramain Madani Energy is a rental service unit for heavy equipment. This business unit has also just opened in the last 2 months. Because there are quite a lot of heavy equipment needs in NTB, this business has provided a lot of income for pesantren. The monthly average income is Rp. 8,000,000, The existing business units are formed one by one in stages, according to the availability of the resources owned by the pesantren. The idea of a business unit in Nurul Haramain boarding schools often arises from the creativity of santris and teachers. The idea was then conveyed to the head of the pesantren. If the resources needed for the operation of a business unit make it possible for the business entity to run smoothly, the business is opened.

The management of each business unit in the pesantren is led by a senior teacher as the person in charge, and is assisted by several junior teachers. Each teacher guides two or three santris in managing business unit operations. Santris who are involved in the pesantren business unit are those chosen by the pesantren according to their talents and interests. Students' entrepreneurial activities are carried out outside formal study 
hours. Entrepreneurship is a non-formal activity like that of scouts, sports groups, music, and others in pesantren. Entrepreneurship is not formally taught in Pesantrens, but it is directly practiced by students who have an interest in developing entrepreneurship and business skills.

Pesantren business management is carried out in the following ways. Business management involving teachers, alumni, santri, community, santris' parents, and the government, both directly and indirectly. Businesses in the Haramain Pesantren aims to improve teacher's and ustadz's welfare. The business is in the name of pesantrens, not in the name of the head of the pesantren and or chairman of the foundation. Business is oriented to increasing the operational budget of Pesantrens. The establishment of a boarding school business unit is aimed at achieving the goals of education in pesantren and at the same time serving as a place of labor, service and empowerment. The existence of a business unit is to raise and develop an existing business by 'transmitting' it to several other Islamic educational institutions (Dahlan, 2019).

There are several field notes obtained from entrepreneurship practices at Nurul Haramain Pesantren, as follows: all the business units are in the name of pesantren, not on personal names. Entrepreneurial activities in Pesantrens are oriented to the support to educational activities in Pesantrens. Nurul Haramain entrepreneurship aims to improve the teachers' welfare. Management of business activities in the pesantren involves all its elements, from the planning, acting, organizing, and up to the distribution. The variety of entrepreneurial activities includes social entrepreneurship, edupreneurship, and religious entrepreneurship. The business unit in Nurul Haramain Pesantren is intended to be continually developed to benefit the wider community. Entrepreneurship is not formally taught but is only introduced through non-formal activities and direct practices (learning by doing the process). 


\section{Future Challenge}

Pesantren as a part that existed within the historical reality of Indonesia are institutions that continue to move and contribute to any changes in Indonesia. Pesantren dialogue with other institutions (unit systems) in the community provides rejuvenation that has an impact on the paradigm shift of pesantren in the management and development of institution. This at least appears at the stage of shifting the identity of pesantren as religious institutions, social institutions, da'wa institutions, educational institutions, and agents of change. The pesantren identity as mentioned above is a label obtained in stages, in accordance with the changing roles taken by pesantren in the process of empowering society in Indonesia. This is what previously written that pesantren possesses academic tradition adaptable to every detail change in society. The flexible academic tradition in the world of boarding schools facilitates the process of shifting the pesantren paradigm (Khun, 1970). Therefore, pesantrens can easily and quickly interact with changes in society. Pesantrens are an inherent part of the body of Indonesian society.

The role of pesantren as written above is inseparable from the figure of the head of the boarding school who oversees its development. A leader of boarding school is known as ulama (religious leader) and their advice takes effect to society. As Isbah (2016) concluded, ulama (kyai) takes many roles in community. Salahuddin (2007) wrote that Tuan Guru (kyai) takes a role as an educator, leader, motivator, adviser or agent of social change. Each kyai has their own area of expertise and specific followers who actively participate in religious counselling programs.

Communication between pesantren is still at the formal level of strengthening pesantren education. Institutions like Communication Forums of Pesantrens are more often used as a place to release emotional desires than intellectuals. The glorious achievement of a pesantren is sometimes ignored by the pesantren community itself. Supposedly, with the 
achievement of one of the pesantren, other pesantren communities should align to strengthen their unity, build power in the name of congregations for economic power. Pesantrens are the real people power that has not been well packaged for the economic revival of the people.

The Islamic economy echoed by some people will only be possible if the pesantren community feels the same and has the same steps to achieve it. Islamic economic idealism entails zakat and waqf as a development instrument (Chapra, 2000). On the other hand, almost all pesantrens begin with waqf and are developed with infaq and sadaqah of the congregations, both because of emotional and intellectual relationships. This means that Muslims, either consciously or subconsciously, have made a significant contribution to the development in Indonesia. Referring to article 34 paragraph (3) of the 1945 Constitution which states that the government is responsible for the procurement of public facilities, with the waqf in the pesantren, Muslims have helped the government in building public facilities and services. The actual idealism of Indonesia's development comes from the purity of the ideas of the pesantren enterprise and the Muslim community. However, righteous and developmental deeds among Muslim communities are not strictly separate. To overcome this, two indicators can be proposed; indicators of piety and indicators of development participation.

Pesantrens as powerful groups in society theoretically have strong potential to revive people's awareness in the economy. Indonesia, in any sort of activity has still to date made pesantren a qibla (direction). Transforming science, transferring empowerment, and strengthening the economy of the community are still the roles highly likely to be played by pesantren. The economic congregations and congregative economy are an effort that must be constructed in the insides of boarding schools, between pesantren, and other pesantren and between pesantren and wider community. 


\section{Conclusion}

Pesantren as a part of units in the Indonesian system well contribute to community development. Their roles may be seen from education, religious affairs, social change, and political movement. Nonetheless, the participation of pesantren has now extended to entrepreneurship and economic development. The participation of its people means that it is not a static institution. It is linked to and developed by the changes in community. The pesantren dynamically adjust and adapt their roles as responses to the changes. Pesantren is not only religious and educational institutions, but they also take a part in economic development and social empowerment. With the academic tradition learned in pesantren, kyai, their students, and people create a new power and contribute to regional economic development. 


\section{References}

Alvarez, S. A., \& Busenitz, L. W. (2003). The entrepreneurship of resourcebased theory. Journal of Management, 29 (3), p. 285-308.

Bellah, Robert N., (1984). Tokugawa Religion: The Values of Pre-Industrial Japan, USA: Macmillan Publisher.

Cromley, J. (2000). Learning to Think, Learning to Learn. Indiana: National Institute for Literacy.

Danaci, H. M. (2015). Creativity and Knowledge in Architectural Education. Procedia - Social and Behavioral Sciences, 174, 1309-1312. https://doi.org/10.1016/j.sbspro.2015.01.752

Dhofier, Zamakhsari, (1982). Tradisi Pesantren Studi Tentang Pandangan Kiai. Jakarta: LP3S.

Everyone, W., \& To, N. (2013). Social entrepreneurship: what everyone needs to know. Choice Reviews Online, 48(02), 48-0968-48-0968. https://doi.org/10.5860/choice.48-0968

Giddens, Anthony (1985) Kapitalisme dan Teori Sosial Modern Modern: Suatu Analisis Karya Tulis Marx, Durkheim dan Max Weber, trans., Jakarta: UI Press.

Irawan, Aguk dan Isfah Abhidal Aziz, (2007), Di Balik Fatwa Jihad Imam Samudera. Yogyakarta: Sajadah Press.

Isbah, M. Falikul, Examining theSocio-Economic Role of Pesantren (Pesantren) in Indoesia, Dissertation, UNSW Canbera, 2016

Jamaludin, M. (2012). Metamorfosis Pesantren di Era Globalisasi. Karsa : The Journal of Social and Islamic Culture. Journal of Social and Islamic Culture, 20(1), 127-139. https://doi.org/http://dx.doi.org/10.19105/ karsa.v21i2.524

Khoerussalim, A., (2007) To be Moslem Entrepreneur. Jakarta: Pustaka AlKautsar 
Khun, Thomas S, (1970), The Structure of Scientific Revolutions. Chicago: University of Chicago Press

Leadbeater, C. (1997). The Rise of the Social Entrepreneur (Demos Papers). Demos, 1-87.

Madjid, Nurcholis, (1997), 'Merumuskan Kembali Tujuan Pendidikan Pesantren', in Kusnanto (ed) Bilik-bilik Pesantren: Sebuah Potret Perjalanan. Jakarta: Paramadina

Mannan, Muhammad Abdul, (1993) Islamic Economics Theory and Practice, trans. Yogyakarta: Dana Bhakti Wakaf.

Mathias, B. D. (2014). Wearing many hats: Role Identity and Entrepreneurship over time. Doctoral Dissertation, 182. Retrieved from http://trace.tennessee.edu/cgi/viewcontent. cgi? article $=3957 \&$ context $=$ utk_graddiss

McKernan, J. (1993). Varieties of curriculum action research: Constraints and typologies in American, British and Irish projects. Journal of Curriculum Studies, 25(5), 445-457. https://doi. org/10.1080/0022027930250504

Muaz, Muhammad Husni, (2014), Anatomi Sistem Sosial Pendekatan Sistem. Mataram: Institut Pembelajaran Gelar Hidup

Muhammad, Y., \& Jolis, A. (1999). Banker to the poor: Micro-lending and the battle against world poverty. Public Affairs.

Overton, Roodney, (2002). Are You an Entrepreneur. Amerika: Wharton Books.

Salahuddin, M. (2007). Tuan Guru dan Pemberdayaan Ekonomi Umat. Mataram: LP2M UIN Mataram.

Schumpeter, J. A. (2003). Jargen G. Backhaus-Joseph Alois Schumpeter: Entrepreneurship, Style and Vision. The European Heritage in Economics and the Social Sciences.

Schumpeter, Joseph A., (2016) The Theory of Economic Development an Inquiry into Profits, Capital, Credit, Interest, and Business Circle. New 
Jersey: The State University of New Jersey

Shane S., (2003), The General Theory of Entrepreneurship The Individual Opportunity-Nexus. Edward Elgar

Suyanto, (2004). Smart in Entrepreneur Belajar Dari Pengusaha Top Dunia. Jakarta: Penerbit Andi.

Van Bruinessen, Martin., (1995). Kitab Kuning Pesantren dan Tarekat. Bandung: Mizan

Van Weert, H. (2010). Nature or nurture? Huisarts En Wetenschap, 53(8), 411. https://doi.org/10.1007/BF03089209

Wahid, A., Harris, P. S., Norton, P. W. W., \& York, N. (2005). Peter Angeles (ed.), Critiques of God: A Major Statement of the Case Against Belief in God (Buffalo: Promotheus Books, 1976). X, 199-212.

Wahid, Salahuddin, (2011), Transformasi Pesantren Tebuireng Menjaga Tradisi Di Tengah Tantangan, Malang, UIN Maliki Press.

Yulianti, (2018). Buddhist Doing Business in Contemporary Indonesia: An Interview with Mr. Sudhamek AWS. Shirkah Journal of Economics and Business Vol. 3, No. 2, p. 179-194.

Yunus, Muhhamad and Weber, K. (2007). Creating World Without Poverty. Public Affairs. https://doi.org/10.1080/15575330.2014.890406 
Vol. 4 No. 2, May - August 2019 


\section{Shirkah Author Guidelines}

Shirkah currently offers two routes to submit manuscripts. We highly recommend to submit the articles which are made using OJS (Open Journal System). Feel free register as author soon through visiting http:// shirkah.or.id/index.php/home/user/register. The authors may directly send their manuscripts, along with their resume, to shirkahiainsurakarta@ gmail.com. Please prepare your manuscripts, using following guidelines:

1. Manuscript must be written in English. Submitted articles should not have been published or be under review for publication with another journal.

2. Manuscript's length is about $15-20$ pages, typed in one-half spaced on A4-paper size.

3. Manuscript must include an $150-200$ word abstract and keywords.

4. Manuscript must be arranged as follows: Title, Name of Author, E-mail address, Abstract, Keywords, Introduction (including method if any), Discussion, Conclusion, References.

5. Manuscript's titles not more than ten words.

6. Manuscript must be submitted in Microsoft Word or RTF.

7. Arabic words should be transliterated according to the style of International Journal of Middle Eastern Studies.

8. Manuscript references are preferably derived from the up-to-date references.

9. The author's resume should be submitted separately, consisting of at least full name, institutional address, phone number, areas of studies, and recent publications (if any).

10. Shirkab use APA Style 6th edition (2010) as reference format writing. We suggest the use of a reference manager software such as Mendeley, Zotero, and Endnote at templating the citation style. APA Style to be used is as follows: 


\section{Book with single author}

Swann, G. M. Peter. (2014). The Economics of Innovation an Introduction. Cheltenhum \& Northampton: Edward Elgar.

in-text citation: (Swann, 2014)

\section{Articles in reference books}

Alatas, S. F. (2006). Islam and the Science of Economics in Abu Rabi', I.M. The Blackwell Companion to Contemporary Islamic Thought. USA: Willey-Blackwell (pp. 587-606).

in text citation: (Alatas, 2006)

\section{E-Book}

Hackett, Rosalind (2007). "Religous Dimentions of War and Peace: Introduction.” Dalam Gerrie ter Haar dan Yoshio Tsuruoka (Ed.), Religion and Society: An Agenda for the 21st Century (h. 3-6). Retrieved from http:// brill.nl.

in text citation: (Hackett, 2006)

\section{Master's thesis, from a commercial database}

McNieI, D. S. (2006). Meaning through narrative: A personal narrative discussing growing up with an alcoholic mother (Master's thesis). Available from ProQuest Dissertations and Theses database. (UMI No. 1434728)

in text citation: (Mc Niel, 2006)

\section{Doctoral dissertation, from an institutional database}

Adams, R. J. (1973). Building a foundation for evaluation of instruction in higher education and continuing education (Doctoral dissertation). Retrieved from http://www.ohiolink.edu/etd/

in text citation: (Adams, 1973) 


\section{Doctoral dissertation, from the web}

Bruckman, A. (1997). MOOSE Crossing: Construction, community, and learning in a networked virtual world for kids (Doctoral dissertation, Massachusetts Institute of Technology). Retrieved from http:/www-static. cc.gatech.edu/--asb/thesis/

in text citation: (Bruckman, 1997)

\section{Journal article with No DOI}

Bourkhis, K., and Nabi, M. S. (2013). Islamic and conventional banks' soundness during the 2007-2008 financial crisis. Journal Metrics, 22(2), 68-77.

in-text citation: (Bourkhis \& Nabi, 2013).

\section{Journal article with DOI}

Ichwan, M. (2012). The Local Politics Of Orthodoxy: The Majelis Ulama Indonesia in the Post-New Order Banten. Journal Of Indonesian Islam, 6(1), 166-194. doi:http://dx.doi.org/10.15642/JIIS.2012.6.1.166-194

In text citation : (Ichwan, 2012)

\section{Abstract as citation}

Hasan, N. (2012). Islamist Party, Electoral Politics And Da'wah Mobilization Among Youth : The Prosperous Justice Party (PKS) in Indonesia. Journal of Indonesian Islam, 6(1), 17-47. Abstract from http:// jiis.uinsby.ac.id/index.php/jiis/article/view/97

in text citation : (Hasan, 2012)

\section{Mass media article}

Sahal, Akhmad (2014, March 2). Kiai Sahal dan Realisme Fikih.Tempo Magazine, p. 120.

in text citation : (Sahal, 2014) 


\section{Research report}

Fisher, B. S., Cullen, F. T., \& Turner, M. G. (2000). The Sexual Victimization of College Women. Research Report.

in text citation : (Fisher, Cullen, Turner, 2000)

\section{Monograph}

Routray, Bibhu Prasad (2013), National Security Decision-Making in India (RSIS Monograph No. 27). Singapura: Rajaratnam School of International Studies.

in text citation : (Routray, 2013)

\section{Proceeding article}

Sudibyakto, Hizbaron, D.R., \& Jati, R (Ed.) (2009), Proceeding International Seminar Disaster Theory, Research and Policy. International seminar held by Sekolah Pascasarjana, Universitas Gajahmada, Yogyakarta, 8-9 Desember 2009.

in text citation : (sudibyakto and Jati, 2009)

\section{Paper conference/seminar/symposium}

Janutama, Herman Sinung (2011). "Kraton dan Hubungan Antar Agama." Paper presented in Seminar Kraton dan Panatagama held by Center for the Study of Islam and Social Transformation (CISForm), Yogyakarta, 17 November.

in text citation :(Janutama, 2011)

\section{Online article in web}

Shiva, (2006, February). Bioethics: A Third World Issue. Native-web. Diperoleh dari http://www.nativeweb.org/ pages/legal/shiva.html

in text citation : (Shiva, 2006) 


\section{Online research report}

Kessy, S. S. A., \& Urio, F M. (2006). The contribution of microfinance institutions to poverty reduction in Tanzania (Research Report No. 06.3). Retrieved from Research on Poverty Alleviation website: http://www. repoa.or.tz /documents_storage/Publications/Reports/06.3_Kessy_and_ Urio.pcif

in text citation : (kessy and urion, 2006)

\section{Holy book}

Qur an, $2(25)$

In text citation : (Q. al-Baqarah 2:25).

\section{Encyclopaedia}

Graycar, Adam (1992). Social Welfare Policy. Dalam Mary Hawkesworth dan Maurice Kogan (Ed.), Encyclopedia of Government and Politics (Vol. 1). London: Routledge.

in text citation : (Graycar, 1992)

\section{Interview}

Sultan Hamengkubuwono X (interview, 2011, April 19)

in text citation: (Hamengkubuwono, 2011)

\section{Documentary film}

Steijlen, Fridus (2008). A Day in the Life of Indonesia [documentary film, 58 minutes]. Leiden: KITLV Press.

in text citation : (Steijlen, 2008) 
Vol. 4 No. 2, May - August 2019 